ISSN 1112-9867

Available online at http://www.jfas.info

\title{
EXPLORING JAHROM MEDICAL UNIVERSITY STUDENTS' ATTITUDES TOWARDS THE ISLAMIC SELF-EVALUATION IN 2015
}

\author{
M. H. Modabber ${ }^{1}$, L. Dezhkam ${ }^{1}$, Z. $\operatorname{Kargar}^{2}$, N. Kalani ${ }^{3 *}$, M. D. Tafvizi ${ }^{4}$, F. Setavand ${ }^{5}$ \\ ${ }^{1}$ Assistant Professor, Medical Ethics Research Center, Medical Sciences University, of Jahrom, \\ Iran \\ ${ }^{2}$ Health Research Center, an expert of operating room, Medical Sciences University of Jahrom, \\ Iran \\ ${ }^{3}$ Department of Anesthesiology, Medical Ethics Research Center, Medical Sciences University of \\ Jahrom, Iran \\ ${ }^{4}$ Masters of philosophy of ethics, medical ethics Research Center, Medical Sciences University of \\ Jahrom, Iran \\ ${ }^{5}$ Student Research Committee, Jahrom University of Medical Sciences, Jahrom, IR Iran
}

Published online: 15 May 2016

\begin{abstract}
Introduction: Self- evaluation is the process of designing, building and maintaining human behaviors that can lead to maturity and perfection. Therefore, the aim of this study is to examine Jahrom Medical University students' attitudes towards the Islamic self-assessment in 2015.

Method: This cross-sectional and descriptive study was carried out on the students of Jahrom University of Medical Sciences in 2015. Using purposive sampling, 223 samples were selected.Collection tool was Islamic self-assessment questionnaire in the form of 20 items based on the Likert scale consisting stipulation, calculating, meditation and expostulation. Data analysis was performed using statistical software SPSS 11 and paired T-test, ANOVA, Pearson correlation.
\end{abstract}

$\overline{\text { Author Correspondence, e-mail: navidkalani@ymail.com }}$

doi: http://dx.doi.org/10.4314/jfas.v8i3s.279 
Results: 223 students participated in this cross-sectional and descriptive study.68.2\% were female and the rest were male. Their average age was $2.18 \pm 20.4$ in the range of 15 to 45 years.28.7 percent of students were medical field and 27.8 percent from the field of Anesthesiology.71.3\% were undergraduates. The results of Pearson correlation coefficient showed that there was a significant correlation between the components of Islamic selfevaluation (stipulation, calculating, meditation, expostulation) and Islamic self-evaluation (Pvalue $<0.05)$.

Conclusion: The students of Jahrom University of Medical Sciences are in relatively good condition in terms of the four stages of Islamic self-evaluation.

Keywords: Islamic self-evaluation, students, Jahrom University of Medical Sciences.

\section{INTRODUCTION}

Islam, with its noble values based on human nature, offers guidelines proportionate to all stages and conditions of life. With respect to the scope of Islamic laws, at the formation of an Islamic government by the Prophet (PBUH) and Ali (AS), their practical inclination is based on Islam and reflects Islamic beliefs and values in the society.In the phase of procedures, they also provide a practical systemwhich can be a guideline for humanity in the management of people and communities. Islam recognizes a status for human thatis unprecedented in any other schools. Quran notifies human that he has been honored by the Lord of the Universe and that he has the potentiality to reach a position that the angels prostrate to him, and before God he can reach to the point thatno angel is capable of attaining. For example, verse 70 of Surah Al-Isra say: "verily we have honored the children of Adam. We carry them on the land and the sea, and have made provision of good things for them, and we have preferred them above many of those whom We created with a marked preferment." Concerning the knowledge of the self and its dignity,in addition to the Holy Quran as the final verdict,we can note some cases among the speech and conductof the Innocents.Imam Hadi (AS) said: "Anyone who is worthless and meanin nature, then you're not safe from his evil" (1).Human looks like a businessman of the Other world that his capital which is his life and soulare his guardian in this way and he must take advantage of this bargain by attaining good morals and virtuous traits and abandoning vices, sins. Selfassessment through communication (stipulation, meditation, calculation, expostulation) can be the way towards the purification of the soul and the movement toward eternal blessing and 
everlasting happiness(2). Stipulation means that human makes a promise with his "self" once a dayso as not to commit any sins and do what would bring out the Lord's displeasure. So, he does need to advise himself concerning the fact that he will see the aftermath ofany conduct that he will do on that day. A man asked for a piece of advice from the Prophet (PBUH),the Prophet said to him three times:"If I should advise you, will you follow it?" And every time that person said: yes. Then, the Prophet said that "any time you are to do anything,ponder over its end, if it is good and you do it but if it does not have a good end, then refrain from doing it altogether (3).Meditation means that the individual is aware of his "self" all day long and takes care of its affairs while whatever he will do, because if the "self" isunleashed, it will forge all the past orders and break covenants.Conditions in which meditation is necessary are that human is aware of God either in rest or movement and considers Him as his watch and knows that God the Almighty is informed of the conscience of all and is the observer of all their actions and the secrets of the hearts are revealed and unfolded to him. Calculation means that the individual sets a time at the end of every day to evaluatehis "self" on the basis of what he had promisedat the beginning of the day.Expostulation means that having evaluated his "self" at the end of the day and found it treacherous and guilty, the individual needs not to neglect and leave it nonsense, because this would make the "self" impudent and render it addicted to betrayal and guilt. So, he is required to blame his "self". (3). Studies conducted on leadership and organizational changes are indicative of the fact that in today's eve-changing working environment, most of the necessary strategic competencies for the workforce of 21 st century are a subset of leadership theories (4).Although a number of leadership theories seem promising to meet the challenges of today, most researchers agree with the fact that effective leadership begins with individual effectiveness.Some leadership theoriesoffer concepts that their principle refers to a person's ability to improve effectiveness and to maximizing the individual's ability.Leadership, in nature, as afactor of promoting the performance can draw special attention as itself.Self-leadership isa process in which people affect themselves to achieve the required self-guidance and spontaneity to act. Drucker (1999) propounds the self-assessment process, which he calls self-management (6). Heifetz (1994), also, explicatesthe process of self-evaluation with emphasis on the individual's knowledge about his beliefsand trends (7).Tychy and Deewana (1990) state thateffective leaders take advantage of self-assessment process to identify their strengths and weaknesses (8).Kozes and Posner (1995) hold thateffective leaders are constantly searching for 
ways to improve themselves and the organization through creating knowledge and thinking in themselves; Therefore, the individual's ability in self-assessment and self-management can be effective in improving his effectiveness and leadership strategies can help the individual in this way (9). In the study conducted byRahimi and colleagues which explored Islamic self-assessment in students of Isfahan University, the results showed that students were in a relatively good condition with respect to the 4 stages of Islamic self-assessmentand that the degree and level of education were effective in Islamic self-assessment attitude in students, but gender did not have any such effect (10).Through a longitudinal study, Hans Berger and colleagues demonstrate that the mean level of suspicion in the youth is at a moderate or balanced level and most uncertaintiesare on the basis of religion's disability in improving people,the Holy Book's immunity from error and slip and the pressure to accept religious education. The emphasis of the Holy Quran and the traditions of the Infallible Imams (AS) as well as their practical conductsare on the fact that each person examines and assesses their own performance and seek to reform them and reinforce their strengths and capabilities in case of perceiving their weaknesses and observing deviations in their performance. Self-assessment, proposedas "calculation" in Islamic literature, has been recommended as a regular daily schedule for each person. This issue has been highlighted to the extent that if one day of man's life elapses and he neglects this program and fails to evaluate his behavior in a careful calculation, he is not considered among the followers of the Holy Prophet (PBUH) and Ahl al-Bayt of the Prophet. The necessity of evaluation of each community members by the community leaders and officials is undeniable because assessment would not only better fulfill the lofty goals of society, but also lead to the progress and excellence of each individual in a unique way. In addition to the assessment that the authorities perform on people,each person is required to have a complete and precisecontrol over their actions and their behavior in any society, environment or organization and assess their own performance to grow and developin various fields.Therefore, the present study was carried out with the aim of examiningIslamic self-assessment attitude in Jahrom Medical University students in 2015.

\section{METHOD}

The present study was a cross-sectional and descriptive study that was conducted on all students of different fields of Jahrom University of Medical Sciences. Sampling from the fields of anesthesia, operating room and nursing, emergency, laboratory sciences, medical and health was 
performed in a census method. To conduct the present study, after getting the approval of the research project and the authorization of the Vice Chancellor for Research and after making an arrangement with officials of medical, nursing and paramedicalschools (including the Vice Chancellor for Student Affairs officials of the two schools) at the proper time (for example, at the end of the morning or evening classes in Departments or in the rest time of the students in the clinical situations), the researcher hands in the research questionnaires to the subjects wishing to participate in the study to fill them out in a quiet and convenient place. Inclusion criteria included: students of different fields atassociate, bachelordegrees and medical fields (including emergency medicine, anesthesiology, medical, etc.) and exclusion criteria included: failure to complete the questionnaires, uncooperative students to participate in the study. It should be noted that the measuring instrument of samples included demographic questionnaireand Islamic selfassessment questionnaire. The demographic questionnaire included age, sex, field of study, level of education, father's occupation, father's education attitude, family income attitude, marital status, place of residenceand the Islamic self-assessment questionnaire with 20 items of response packets according to the Likertfive-degree scale (strongly disagree, disagree, have no idea, agree andstrongly agree) was scored.Islamic self-evaluation score was calculated from the average of all the questions. Islamic self-evaluation scores were divided into three levels of low $(2.33<)$, medium (2.33-3.66), high $(3.67>=)$. Questionnaire total score was 5-0. This questionnaire consisted of four components (stipulation, calculating, meditation and expostulation) and each area included five questions. It should be noted thatthe validity and reliability of the aforementioned questionnaire was determined $94 \%$ by R. Aghababaei and colleagues at the University of Medical Sciences in Iran. The reliability of the mentioned questionnaire was tested with a pilot study of 30 people. In order to comply with ethical considerations, prior to collecting data from thestudied subjects in the research, first, the necessary explanations (such as the purpose and use of the present study) were presented and the subjects were assured thatthe data obtained from the study would be kept confidential and there was no need to mention first name and surname in the questionnaire. Data analysis was performed at the level of inferential statistics (t-test, ANOVA, Pearson correlation) using the statistical software SPSS version 11. 


\section{RESULTS}

223 students participated in this cross-sectional and descriptive study.68.2\% were female and the rest were male.Their average age was $2.18 \pm 20.4$ in the range of 15 to 45 years. $85.2 \%$ were single. 28.7 percent of students were medical field and 27.8 percent from the field of Anesthesiology. $71.3 \%$ were undergraduates. $77.6 \%$ percent were non-native and $57.4 \%$ of them had moderate income families.78.2 percent lived in dormitories and 17.3 percent lived with their parents. Moreover, the father's job of 50.7 percent of the students was self-employed and the remaining had governmental occupations (Table 1).

Table 1. Descriptive analysis of demographic variables

\begin{tabular}{|c|c|c|c|}
\hline Percent & frequency & Level & Variable \\
\hline $31.8 \%$ & 71 & Male & \multirow{2}{*}{ Gender } \\
\hline $68.2 \%$ & 152 & Female & \\
\hline $85.2 \%$ & 190 & Single & \multirow[t]{2}{*}{ Marital status } \\
\hline $14.8 \%$ & 33 & Married & \\
\hline $28.7 \%$ & 64 & Medical & \multirow{6}{*}{ Field of study } \\
\hline $5.8 \%$ & 13 & Health & \\
\hline $17 \%$ & 38 & Laboratory Sciences & \\
\hline $14.8 \%$ & 33 & Nursing & \\
\hline $27.8 \%$ & 62 & Anesthesiology & \\
\hline $5.8 \%$ & 13 & Operating Room & \\
\hline $71.3 \%$ & 159 & Bachelor & \multirow{2}{*}{ Level of education } \\
\hline $28.7 \%$ & 64 & Professional doctor & \\
\hline $3 \%$ & 6 & Low & \multirow{3}{*}{ Family income } \\
\hline $64.6 \%$ & 128 & Moderate & \\
\hline $32.3 \%$ & 64 & High & \\
\hline $21.7 \%$ & 48 & Native & \multirow{2}{*}{ Native } \\
\hline $78.3 \%$ & 173 & None-native & \\
\hline $49.3 \%$ & 104 & Governmental & \multirow[t]{2}{*}{ Father's job } \\
\hline $50.7 \%$ & 107 & Self-employed & \\
\hline $23.9 \%$ & 50 & High school & \multirow[t]{6}{*}{ Father's education } \\
\hline $30.6 \%$ & 64 & Diploma & \\
\hline $13.4 \%$ & 28 & Associate & \\
\hline $22 \%$ & 46 & Bachelor & \\
\hline $6.7 \%$ & 14 & Master & \\
\hline $3.3 \%$ & 7 & $\mathrm{PhD}$ & \\
\hline $78.2 \%$ & 172 & Dormitory & \multirow[t]{3}{*}{ Residence } \\
\hline $17.3 \%$ & 38 & With parents & \\
\hline $4.5 \%$ & 10 & Rental & \\
\hline
\end{tabular}


Changes in Islamic self-assessment scores and its components instudents are from 1 to 5 . Higher scores indicate higher Islamic self-assessment in the individual. The average Islamic selfassessment among the students Jahrom University of Medical Sciences was $0.572 \pm 4.05$. Among the components of Islamic self-assessment, the highest score was attributed to meditation $(0.675$ \pm 4.18 ) (Table 2).

Table 2. Descriptive analysis of independent and dependent variables

\begin{tabular}{|c|c|c|c|c|}
\hline Maximum & Minimum & $\begin{array}{l}\text { Standard } \\
\text { Deviation }\end{array}$ & Average & \\
\hline 5.000 & 1.800 & 0.590 & 3.951 & Stipulation \\
\hline 5.000 & 1.400 & 0.653 & 3.949 & Calculation \\
\hline 5.000 & 1.000 & 0.657 & 4.180 & Meditation \\
\hline 5.000 & 1.000 & 0.727 & 4.039 & Expostulation \\
\hline 5.000 & 1.300 & 0.572 & 4.053 & $\begin{array}{l}\text { Islamic self- } \\
\text { assessment }\end{array}$ \\
\hline
\end{tabular}

Islamic self-evaluation scores were divided into three levels of low $(2.33<)$, medium $(2.33$ 3.66), high $(3.67>=)$. Islamic self-assessment of 76.7 percent of the students was at a high level (Table 3).

Table 3. Islamic self-assessment level of the Jahrom University of Medical Sciences

\begin{tabular}{|c|c|c|}
\hline Percent & Frequency & Islamic self-assessment level \\
\hline 0.09 & 2 & Low $(<2.33)$ \\
22.4 & 50 & Average $(2.34-3.66)$ \\
76.7 & 171 & High $(>=3.67)$ \\
& & \\
\hline
\end{tabular}

Comparing Islamic self-assessment in terms of demographic variables in Table 4 indicated that there was a significant correlation among gender, marital status, father's education, family income attitude and parents' Islamic self-evaluation (value $<$ P-0.05). But,there was no significant correlation among the variables of field of study, level of education, father's occupation, place of residence, being indigenous Islamic self-evaluation $(\mathrm{P}-\mathrm{value}<0.05)$. 
The average of Islamic self-assessment was higher in female studentsthan male students and, likewise, it was higher in married students than singles. The highest average of Islamic selfassessment was observed in nursing students; however there was no statistically significant difference between the fields. Students with higher family income enjoyed higher selfassessment.

Table 4. Comparison of Islamic self-assessment in terms of demographic variables

\begin{tabular}{|c|c|c|c|c|}
\hline P-value & $\begin{array}{l}\text { Standard } \\
\text { Deviation }\end{array}$ & Average & Level & Variable \\
\hline \multirow[t]{2}{*}{$\mathrm{p}<0.001^{*}$} & 0.72 & 3.79 & Male & \multirow{2}{*}{ Gender } \\
\hline & 0.45 & 4.17 & Female & \\
\hline \multirow[t]{2}{*}{$\mathrm{p}<0.001^{*}$} & 0.57 & 4.00 & Single & \multirow{2}{*}{$\begin{array}{l}\text { Marital } \\
\text { status }\end{array}$} \\
\hline & 0.43 & 4.34 & Married & \\
\hline \multirow[t]{6}{*}{$0.163^{* *}$} & 0.51 & 4.05 & Medical & \multirow{6}{*}{$\begin{array}{l}\text { Field of } \\
\text { study }\end{array}$} \\
\hline & 0.25 & 4.16 & Health & \\
\hline & 0.47 & 3.99 & Laboratory Sciences & \\
\hline & 0.59 & 4.28 & Nursing & \\
\hline & 0.68 & 3.96 & Anesthesiology & \\
\hline & 0.54 & 3.95 & Operating Room & \\
\hline \multirow[t]{2}{*}{$0.957^{*}$} & 0.59 & 4.05 & Bachelor & \multirow{2}{*}{$\begin{array}{l}\text { Level of } \\
\text { education }\end{array}$} \\
\hline & 0.51 & 4.06 & Professional doctor & \\
\hline \multirow{3}{*}{$0.019^{* * *}$} & 1.18 & 3.34 & Low & \multirow{3}{*}{$\begin{array}{l}\text { Family } \\
\text { income }\end{array}$} \\
\hline & 0.574 & 4.05 & Moderate & \\
\hline & 0.491 & 4.04 & High & \\
\hline \multirow[t]{2}{*}{$0.965^{*}$} & 0.66 & 4.06 & Native & \multirow{2}{*}{ Native } \\
\hline & 0.54 & 4.05 & None-native & \\
\hline \multirow[t]{2}{*}{$0.573^{*}$} & 0.60 & 4.07 & Governmental & \multirow[t]{2}{*}{ Father's job } \\
\hline & 0.54 & 4.04 & Self-employed & \\
\hline \multirow[t]{6}{*}{$0.020^{* *}$} & 0.61 & 4.05 & High school & \multirow{6}{*}{$\begin{array}{l}\text { Father's } \\
\text { education }\end{array}$} \\
\hline & 0.57 & 3.93 & Diploma & \\
\hline & 0.39 & 4.34 & Associate & \\
\hline & 0.58 & 3.98 & Bachelor & \\
\hline & 0.40 & 4.21 & Master & \\
\hline & 0.59 & 3.76 & $\mathrm{PhD}$ & \\
\hline \multirow[t]{3}{*}{$0.473^{* *}$} & 0.50 & 4.05 & Dormitory & \multirow[t]{3}{*}{ Residence } \\
\hline & 0.66 & 4.10 & With parents & \\
\hline & 1.05 & 3.83 & Rental & \\
\hline
\end{tabular}


The results of Pearson correlationin Table 5 show that there is a significant correlation between the components of Islamic self-evaluation (stipulation, calculating, meditation, expostulation) and Islamic self-evaluation (P-value $<0.05)$.

Table 5. Evaluation of relation between the components of Islamic self-evaluation and Islamic self-assessment by using Pearson's correlation coefficient

\begin{tabular}{|c|c|c|c|c|l|}
\hline Expostulation & Meditation & Calculation & Stipulation & \multicolumn{2}{|l|}{ Variable } \\
\hline 0.861 & 0.897 & 0.865 & 0.815 & r & Islamic \\
$\mathrm{p}<0.001^{*}$ & $\mathrm{p}<0.001^{*}$ & $\mathrm{p}<0.001^{*}$ & $\mathrm{p}<0.001^{*}$ & $\begin{array}{c}\text { P- } \\
\text { value }\end{array}$ & $\begin{array}{l}\text { self- } \\
\text { assessment }\end{array}$ \\
\hline
\end{tabular}

\section{DISCUSSION}

According to religious texts and sources, we discover thatIslam has attributed great importance to "assessment" and this evaluation includesthe surveillance of rulers and elders over the actions of subordinates, as well as each person's internal monitoring on their own actions. Islam casts much more emphasis on the latter type, say self-assessment.Pearson correlation test revealed that the average of each component of self-assessment is above average. In other words, students have a relatively good position in terms of each component of self-assessment. The highest average belongs to "meditation" component with an average of 20.90 and the lowest average belongs to "calculation" component with an average of 19.74. This suggests that "meditation" component is in a better position compared to the other three components. The results of the main hypothesis of the presentare consistent and corresponding with the results of studies conducted by KhodayariFar and colleagues, Azerbaijani, Smith, Faris, and Aghababaei. In their research, Khodayari Far and Azerbaijani concluded that the level of being religious among the students was above average. Smith and Farisshowed that most US teens had stated that religious beliefs played an important role in their lives (13-12). Table 2 shows that there is a significant positive relationship between each component of self-assessment. Table 3 demonstrates that there is no significant relationship between the variable such as the level of education, father's occupation, place of residence, being indigenous and Islamic self-assessment and cannot be used in the regression model.This means that these factors do not have a significantly determining role in Islam in self-assessment. The study results are coherent with the results of the study conducted by 
Alavi (14) and Keshavarz (15).Alavi understood that there is no significant relationship between students' religious behavior and their educational grade and that educational grade does not have any statistically significant role in self-assessment.Keshavarz concluded that there is no significant relationshipbetween occupation and education of parents and their attitudes to religion, but there is a significant relationship between cost and income andreligious attitude.

\section{CONCLUSION}

The students of Jahrom University of Medical Sciences are in relatively good condition in terms of the four stages of Islamic self-evaluation.Gender is effective in the students' Islamic selfevaluation, while field of study and educational level fail to have such an effect.

\section{REFERENCES}

1. Ebn Shieh AM. Tofato oghol an al Rasul. 2nd ed. Qom:Institution Islamic Publication; 1985.

2- Feiz Kashani M. Almohjato albeiza. Beirut: Scientific Institution of Magazine; 1982.

3- Naraghi MA. Well-being ascension. 2nd ed. Tehran: Ghaem Al Mohammad Publication; 2006.

4- Pearce, C. L. \& J. A. Conger (2003), Shared leadership: Reframing the hows \& whys of leadership, Thousand Oask,CA: sage publications, Inc.

5- Houghton, J. D.; T. W.Bonhom; C. P. Neck \& K. Sing (2004), "The relationship between selfleadership and personality: A comparison of hierarchical factor structures", Journal of Managerial psychology, 1, pp.424-441.

6- Drucker, P. F. (1999), Management challenges for the 21 century, New York, NY: HJarper Collins Publishers, INC.

7- Heifetz, R. (1994), Leadership without easy answers, Cambridge, MA: Belnap Press of Harvard University Press.

8- Tichy, Nm. M. \& M. A. Devanna (1990), The transformational leader, New York: NY: John Wiley \& Sons, Inc.

9- Kouzes, J. M. \& B. Z. Posner (1995), The leadership challenge, (2nd ed,), New Yord NY: oJessey - Bass.

10- Agha Babayi R, Nasr Isfahani A, Rahimi. Level of Islamic self assessment in students; Isfahan University. Iranian Quarterly of Education Strategies, Vol. 5, No. 2, Summer 2012: 119124. 
11-Bergin AE. Values and religious issues in psychotherapy and mental health. Am Psychol. 2004;46(4):394-403.

9- Khodayari-Fard M, Ghobari B. The prepare scale of religion attitude and belief measurement in student in university of Sharif. Tehran: University of Sharif; 2000. [Persian]

10- Azarbaygani M. Religion attitude test base on Islam view [dissertation]. Qom: Hozeh and University Publication; 2002.

11- Alavi HR. The study of religion behavior and related factors in high school teenagers in Kerman. Kerman Univ Med Sci J. 2007;1(2):99-114. [Persian]

12- Keshavarz A. The study of relationship between economic and social base in students and their religion attitudes. J Prof Ethic. 2011;5(2):9-14.

\section{How to cite this article:}

Modabber MH, Dezhkam L, Kargar Z, Kalani N, Tafvizi MD, Setavand F. Exploring jahrom medical university students' attitudes towards the islamic self-evaluation in 2015. J. Fundam. Appl. Sci., 2016, 8(3S), 988-998. 